Abstracta Iranica

Revue bibliographique pour le domaine irano-aryen

Volume 32-33 | 2013

Comptes rendus des publications de 2009-2010

\title{
Kaan Iren. A new Discovery in Dascylium: The Persian Destruction Level
}

\section{Rémy Boucharlat}

\section{(2) OpenEdition}

1 Journals

Édition électronique

URL : http://journals.openedition.org/abstractairanica/40297

DOI : 10.4000/abstractairanica.40297

ISSN : 1961-960X

\section{Éditeur :}

CNRS (UMR 7528 Mondes iraniens et indiens), Éditions de l'IFRI

\section{Édition imprimée}

Date de publication : 1 décembre 2013

ISSN : 0240-8910

\section{Référence électronique}

Rémy Boucharlat, « Kaan Iren. A new Discovery in Dascylium: The Persian Destruction Level », Abstracta Iranica [En ligne], Volume 32-33 | 2013, document 78, mis en ligne le 01 juillet 2016, consulté le 05 octobre 2020. URL : http://journals.openedition.org/abstractairanica/40297 ; DOI : https://doi.org/ 10.4000/abstractairanica.40297

Ce document a été généré automatiquement le 5 octobre 2020.

Tous droits réservés 


\title{
Kaan Iren. A new Discovery in Dascylium: The Persian Destruction Level
}

\author{
Rémy Boucharlat
}

\section{RÉFÉRENCE}

Kaan Iren. « A new Discovery in Dascylium: The Persian Destruction Level », in : P. Matthiae, F. Pinnock, L. Nigro, N. Marchetti, eds., Proceedings of the 6th International Congress of the Archaeology of the Ancient Near East, 5 May-10 May 2009 « Sapienza »Università di Roma. Vol. 2, Wiesbaden, Harrassowitz, 2010, p. 249-263, 10 fig.

1 La tentation est toujours forte de mettre en relation un incendie et un épisode violent de la vie d'une cité. Naguère, T. Bakır avait pensé trouver le niveau de destruction correspondant à la prise par Alexandre de la ville capitale de la satrapie de Phrygie hellespontique (N.O. de l'Asie Mineure). Cette fois, pour le nouveau directeur des fouilles, ce serait les traces de la prise de la ville par Cyrus. Une date est donnée par une céramique attique précisément datée, du troisième quart $\mathrm{du} \mathrm{VI} \mathrm{I}^{\mathrm{e}} \mathrm{s}$. av.n.è. La fouille, très limitée actuellement, est celle d'un espace de cuisine qui a pu brûler pour d'autres raisons que la guerre. 


\section{AUTEURS}

RÉMY BOUCHARLAT

CNRS, Lyon 